\title{
Modeling Distribution of Selective Ions in Urban and Rural Areas Using Geographical Information System
}

\author{
Nezar H. Khdary ${ }^{1,2}$, Ahmed E. Gasim² ${ }^{2}$ Muhammed E. Muriani², Ali A. Alshehrie ${ }^{1}$ \\ ${ }^{1}$ King Abdulaziz City for Science and Technology, Riyadh, KSA \\ ${ }^{2}$ Research Unit, Makkah Toxicology Center, Ministry of Health, Makkah, KSA \\ Email: $\underline{\text { nkhdary@kacst.edu.sa }}$
}

Received 12 March 2015; accepted 17 April 2015; published 20 April 2015

Copyright (C) 2015 by authors and Scientific Research Publishing Inc.

This work is licensed under the Creative Commons Attribution International License (CC BY). http://creativecommons.org/licenses/by/4.0/

(c) $\underset{\mathrm{EY}}{\mathrm{Er}}$ Open Access

\begin{abstract}
The main objective of this study is to evaluate the distributions of selective ions in Makkah wells using GIS. The present study focuses on the presence and accumulation of several ions in the ground water of Makkah City. This study exhibits selected measurements of the levels and distribution of 4 ions (nitrate, nitrite, chloride and sulphate) in wells water using the Geographical Information System (GIS). The study covered 27 areas of Makkah City and its environs. Two layers were made using the Arc-Map program: the first layer was called internal wells (Central Makkah, urban) and the second layer was called external wells (rural). The total number of wells covered by this study was 145 , and the samples were collected in different seasons. The samples were analyzed following standard procedures and compared with local and international standards. The results showed that the relative abundance of the major ions in the ground water was $\mathrm{SO}_{4}>$ $\mathrm{Cl}^{-1}>\mathrm{NO}_{3}>\mathrm{NO}_{2}$, with the presence of $\mathrm{SO}_{4}$ being dominant.
\end{abstract}

\section{Keywords}

Component, Nitrate, Nitrite, Chloride, Sulphate, Makkah, Well Water

\section{Introduction}

Makkah (Mecca) is located in the western region of Saudi Arabia called Al-Hijaz. The city is situated between

\footnotetext{
${ }^{*}$ Corresponding author.
} 
the Red Sea, 75 kilometers from the west (Jeddah), and Taif City, 68 kilometers from the east [1]. Taif City is located in part of the Sarawat Mountains, 1700 meters above sea level, while Makkah is 300 meters above sea level. Makkah is situated in Abraham Valley, and its coordinates are: $21^{\circ} 25^{\prime} 0^{\prime \prime} \mathrm{N}, 39^{\circ} 49^{\prime} 0$ "E (World Geodetic System, WGS84). The importance of Makkah, as the Holy City for Muslims, leads to the arrival of millions of pilgrims and visitors annually to offer Hajj and Umrah. These millions of visitors, as well as residents of the city, constitute a burden on water sources. However, the government has covered most of the water demands with desalination water, while the rest of the shortage of water for Makkah (urban and rural) is secured from wells [2].

Water is a crucial resource for all components of life on earth. Groundwater is generally assumed to be noncontaminated for human consumption, and an accessible source for drinking water. The main natural resources of water include surface water and groundwater [3] [4]. Groundwater is considered to be the most important source of drinking water of the four main water resources: surface water, groundwater, desalinated seawater and treated wastewater in the Kingdom of Saudi Arabia [5] [6]. Groundwater originates in shallow renewable aquifers and deep nonrenewable aquifers. The shallow aquifers consist of surface runoff and a renewable water stream preserved by surface runoff and rainfall. The rain seasons and heavy rain have an extreme impact on rock erosion which leads to dissolve elements and groups of chemical in aquifers [7]. Water trapped in sedimentary rocks results in the formation of reservoirs, such as limestone and sandstone in the deep aquifers [8].

For the present study, the wells were selected from the southern Hijaz region and west-central Arabian Shield of Makkah. Fundamentally, the groundwater is runoff which permeates from metamorphic igneous rocks through the Wadi sediment to the aquifers. These areas are dominated by the three main rock types: igneous, metamorphic and sedimentary rocks from the Precambrian and Lower Paleozoic eras. In addition to the three main rock types, the selected area consists of subordinate sedimentary rocks and basaltic lava flow from the tertiary and quaternary periods. The Makkah area is mainly covered with Precambrian intrusive rocks and intermediate rocks, ranging in composition from diorite to tonalite. The three major phases of Precambrian deformation and tertiary faulting are the dominant structural trend towards northeast of the Makkah area [9].

The main sources of groundwater pollution are agricultural practices, localized industrial activities and inadequate or improper disposal of wastewater and solid waste [10] [11]. Nitrate and nitrite ions are taking place naturally. Nitrite ion $\left(\mathrm{NO}_{2}\right)$ is an intermediate and unstable ion because of oxidation state, which oxides to convert nitrite to nitrate $\left(\mathrm{NO}_{3}\right)$. However, Nitrate $\left(\mathrm{NO}_{3}\right)$ could also be reduced by some microbial agents [12] [13].

The pollution of ground water due to nitrate is a worldwide problematic issue due to point and nonpoint sources [14]-[16]. Its solubility and negative charge increase the mobility and potential for loss from the unsaturated zone by leaching [17]. Elevated levels of nitrite and nitrate in drinking water could lead to methemoglobinemia or blue baby syndrome in infants, and thyroid and reproductive problems in adults [18]-[20]. Sulphate is a ubiquitous component of groundwater, being derived from a variety of sources; naturally, it arises from several minerals, such as epsomite $\left(\mathrm{MgSO}_{4} \cdot 7 \mathrm{H}_{2} \mathrm{O}\right)$, gypsum $\left(\mathrm{CaSO}_{4} \cdot 2 \mathrm{H}_{2} \mathrm{O}\right)$ and barite $\left(\mathrm{BaSO}_{4}\right)$ [21]. Residential, atmospheric, industrial and agricultural wastes are the main anthropogenic sources of sulphate [22]. Sodium, potassium and magnesium sulphate are all very soluble in water, whereas calcium and barium sulphates are less soluble [23] [24]. Sulphate is generally considered to be non-toxic; nevertheless, the consumption of drinking water containing high concentrations of magnesium or sodium sulphate may result in intestinal discomfort, diarrhea and consequent dehydration. The laxative result could happen because of high concentration of sulphate specially when conjoined with the calcium and magnesium, which also cause water hardness [25] [26]. Sulphate-reducing bacteria are often encountered in water supplies; these bacteria produce hydrogen sulphide which causes an unpleasant taste and odor [27].

Sources of chloride in groundwater are both natural and manmade [28]. Water is a very good solvent which completely dissolves the chloride from topsoil and deeper soil layers [29] [30]. It is an essential element in humans for maintaining the proper osmotic pressure and water balance in tissues. It is non-toxic to humans, but when the concentration of chloride reaches $250 \mathrm{mg} / \mathrm{L}$ or above, it can be detected in the taste of the water [31]. Chloride ions usually react with the metal composition in the water lines made from metals or metals alloyed; the corrosion effect could be increasing because of the increasing in chloride concentration that leads to leaching the metals in water [32].

In this work, the concentrations of $\mathrm{Cl}^{-1}, \mathrm{SO}_{4}, \mathrm{NO}_{2}$ and $\mathrm{NO}_{3}$ were determined and the distributions of these ions in Makkah water wells were evaluated using Geographical Information System (GIS). 


\section{Materials and Methods}

\subsection{Well Locations Using GPS}

In this study 27 districts in Makkah were cover $\left(21^{\circ} 25^{\prime} \mathrm{N}, 39^{\circ} 49^{\prime} \mathrm{E}\right)$. Table 1, illustrates the central location of each district enclosed in this work. The locations mostly from nonrenewable sources; frequent runoff water from metamorphic igneous rocks that seeps through the valley sediment to aquifers. Each well was located using Global Positioning System (GPS). The total number of wells covered was 145 as shown in Figure 1.

\subsection{Chemicals and Instruments}

The stock solutions (1000 ppm) of sulphate, chloride, nitrate and nitrite were prepared from their original salts by dissolving the appropriate weight in 1 liter volumetric flasks, and then several dilutions were carried out to prepare the standard solutions. All solutions were prepared using deionized water $(18 \mathrm{M} \Omega-\mathrm{cm})$. The samples

\section{Table 1. Selected locations and number of wells in Makkah City.}

\begin{tabular}{|c|c|c|c|c|c|}
\hline \multirow{2}{*}{ No. } & \multirow{2}{*}{ Symbols } & \multirow{2}{*}{ Areas } & \multirow{2}{*}{ No. of wells } & \multicolumn{2}{|c|}{ Geographic coordinates for each district central } \\
\hline & & & & $\mathrm{E}$ & $\mathrm{N}$ \\
\hline 1 & A & Am AL-Jawad & 12 & $39^{\circ} 43.950$ & $21^{\circ} 25.733$ \\
\hline 2 & $\mathrm{~B}$ & AL-Jamoom & 10 & $39^{\circ} 44.694$ & $21^{\circ} 41.664$ \\
\hline 3 & $\mathrm{C}$ & Al-Hussinia & 5 & $39^{\circ} 51.150$ & $21^{\circ} 18.699$ \\
\hline 4 & $\mathrm{D}$ & AL-Rayan & 12 & $39^{\circ} 54.863$ & $21^{\circ} 40.928$ \\
\hline 5 & $\mathrm{E}$ & AL-Sanoosih & 6 & $39^{\circ} 56.125$ & $21^{\circ} 34.142$ \\
\hline 6 & $\mathrm{~F}$ & AL-Shumaisi & 6 & $39^{\circ} 37.941$ & $21^{\circ} 26.313$ \\
\hline 7 & G & AL-Digah & 3 & $39^{\circ} 49.380$ & $21^{\circ} 33.166$ \\
\hline 8 & $\mathrm{H}$ & AL-Gobaiah & 6 & $39^{\circ} 57.524$ & $21^{\circ} 41.932$ \\
\hline 9 & I & AL-Moghmas & 2 & $40^{\circ} 00.145$ & $21^{\circ} 27.604$ \\
\hline 10 & $\mathrm{~J}$ & AL-Wasiah & 4 & $39^{\circ} 51.150$ & $21^{\circ} 18.699$ \\
\hline 11 & K & AL-Yamaniah & 2 & $40^{\circ} 05.454$ & $21^{\circ} 37.638$ \\
\hline 12 & $\mathrm{~L}$ & Bani-Omer & 6 & $40^{\circ} 03.961$ & $21^{\circ} 39.269$ \\
\hline 13 & M & Swlah & 4 & $40^{\circ} 05.454$ & $21^{\circ} 37.638$ \\
\hline 14 & $\mathrm{~N}$ & Sharai AL-Nikhil & 4 & $40^{\circ} 02.448$ & $21^{\circ} 30.674$ \\
\hline 15 & $\mathrm{O}$ & AL-Lith Road & 1 & $39^{\circ} 36.340$ & $21^{\circ} 10.544$ \\
\hline 16 & $P$ & Wadi Noman & 23 & $40.00^{\circ} .230$ & $21^{\circ} 19.264$ \\
\hline 17 & Q & Wadi Elaf & 4 & $39^{\circ} 53.405$ & $21^{\circ} 42.317$ \\
\hline 18 & $\mathrm{R}$ & AL-Fihah & 1 & $39^{\circ} 45.652$ & $21^{\circ} 27.264$ \\
\hline 19 & $\mathrm{~S}$ & AL-Kakia & 2 & $' 39^{\circ} 48.535$ & $21^{\circ} 23.344$ \\
\hline 20 & $\mathrm{X}$ & AL-Sobhani & 7 & $39^{\circ} 47.135$ & $21^{\circ} 21.776$ \\
\hline 21 & $\mathrm{Y}$ & Gazah & 1 & $39^{\circ} 49.740$ & $21^{\circ} 25.663$ \\
\hline 22 & $\mathrm{Z}$ & AL-Omrah & 4 & $39^{\circ} 47.392$ & $21^{\circ} 30.162$ \\
\hline 23 & MS & AL-Mesfalah & 3 & $39^{\circ} 49.364$ & $21^{\circ} 24.958$ \\
\hline 24 & $\mathrm{MN}$ & AL-Twndibawi & 5 & $39^{\circ} 48.587$ & $21^{\circ} 24.571$ \\
\hline 25 & $\mathrm{NZ}$ & AL-Zahir & 6 & $39^{\circ} 47.643$ & $21^{\circ} 26.478$ \\
\hline 26 & $\mathrm{BH}$ & Batha Quraysh & 3 & $39^{\circ} 49.395$ & $21^{\circ} 21.175$ \\
\hline 27 & SH & AL-Hajj Road & 3 & $39^{\circ} 50.562$ & $21^{\circ} 27.367$ \\
\hline
\end{tabular}




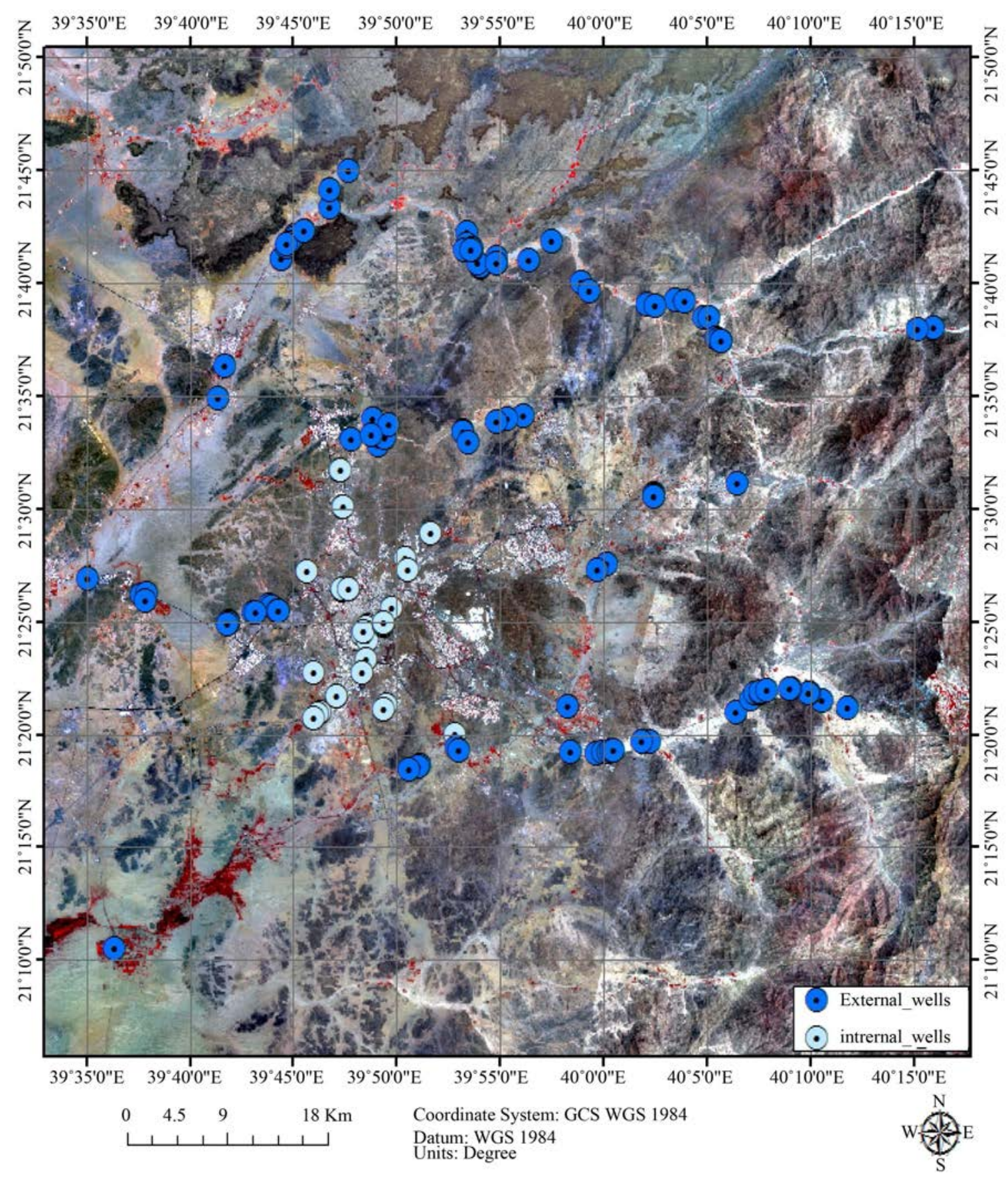

Figure 1. Satellite image of the whole area covered in this study, including internal and external wells.

were analyzed using the Dionex 1CS-2100 Ion Chromatograph coupled with an IonPacAG18 and AS18 column. The analytes were detected using a conductivity detector. The eluent was sodium carbonate and bicarbonate in different molar ratios, the flow rate of the eluent was $2.0 \mathrm{ml} / \mathrm{min}$, and the injection volume was $10 \mu 1$. The Garmin GPSMAP276C was utilized to locate the geographical coordinates for each well. ESRI ${ }^{\circledR}$ ArcMap version 10 was used to build up the database and layers.

\subsection{Sample Collection, Times and Locations}

The samples were collected from 145 wells which included 27 areas of Makkah City and its environs. The sam- 
ples were collected during April, May, June and July. The sampling was once per month during the three years of investigation 2007-2009. Standard methods were followed for sample collection, transportation and analysis. All precautionary steps were taken in to account to avoid any cross-contamination. Water samples were collected in high density polyethylene bottle, which labeled and rinsed with $10 \% \mathrm{HCl}$, and then rinsed with deionized water 3 times until the $\mathrm{pH}$ of the rinsed water was around 7 and then left to dry at room temperature. Each sample was collected after 10 minutes of water flow from the tube well pump. The samples were sent to the laboratory immediately for analysis. In the cases of the samples collected late in the day, the samples were then kept in the refrigerator at $4^{\circ} \mathrm{C}$ for stabilization until the next day for analysis.

\section{Results and Discussion}

The distribution of the average concentrations of the four ions studied; nitrate $\left(\mathrm{NO}_{3}\right)$, nitrite $\left(\mathrm{NO}_{2}\right)$, chloride $\left(\mathrm{Cl}^{-1}\right)$ and sulphate $\left(\mathrm{SO}_{4}\right)$ is illustrated in Figure 2. The order of the relative abundance of the major ions in the

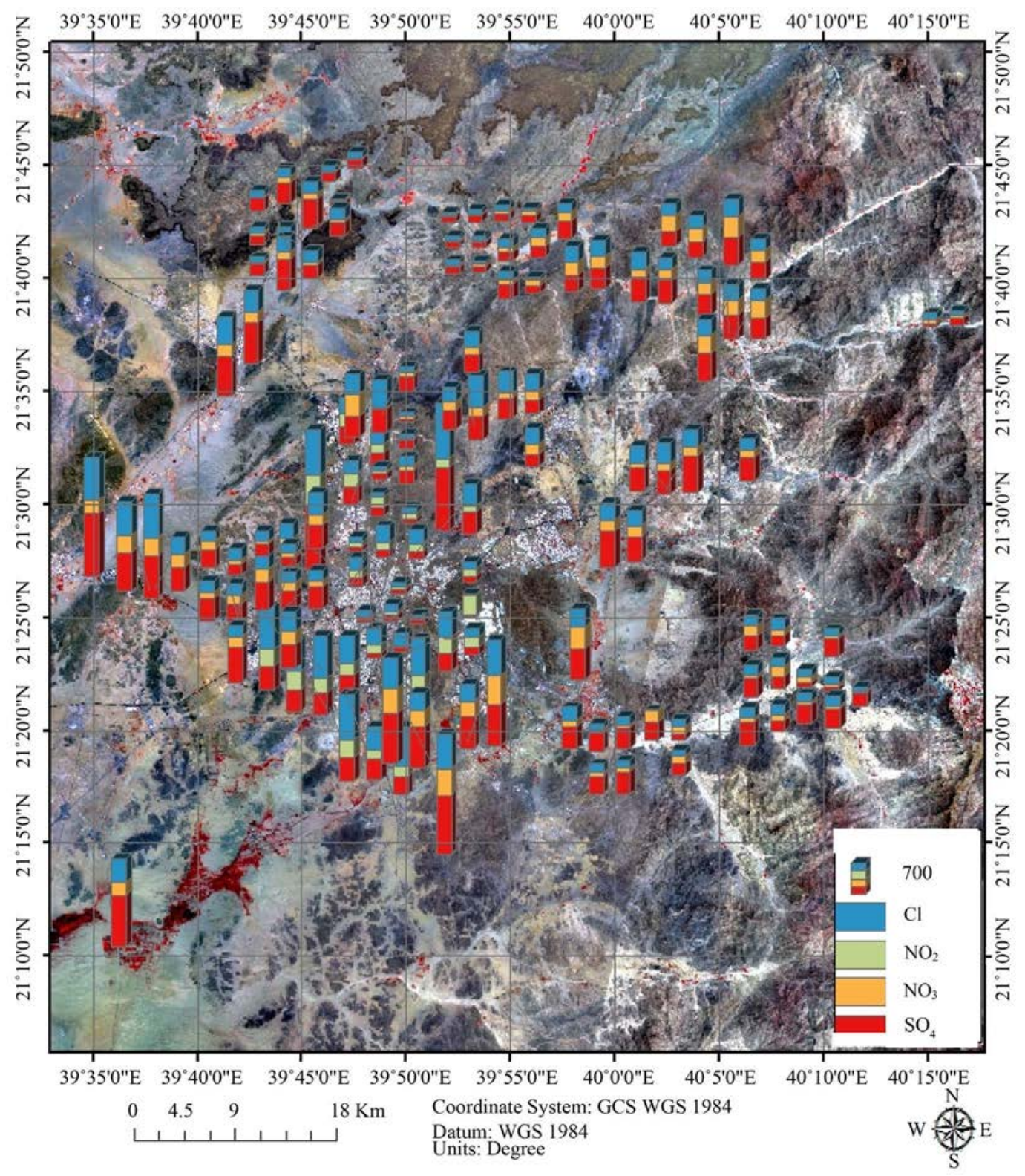

Figure 2. Distribution of chlorides, nitrate, nitrite and sulphate in Makkah wells. 
groundwater was $\mathrm{SO}_{4}>\mathrm{Cl}^{-1}>\mathrm{NO}_{3}>\mathrm{NO}_{2}$, with the presence of $\mathrm{SO}_{4}$ being dominant, as shown in Table 2. The wide range of the chemical composition of the ground water suggests that it arises from the source and circulation of the water itself into the aquifer media, whereas geology imposes the chemistry on the groundwater composition [33].

The nitrate concentrations ranged between 23 and $700 \mathrm{mg} / 1$, with an average value of $213.4 \mathrm{mg} / 1$ (Figure 3). Based on the Saudi Arabian Standard Organization (SASO, 1984) and European Union (EU, 1998) drinking water quality standards, 130 wells $(89.6 \%)$ were found to be above the permissible limit. According to the Environmental Protection Agency (2011) and World Health Organization (WHO, 2010), the standards in only 126 wells $(86.9 \%)$ fell above the permissible limits. The wide variation in nitrate levels among the wells could

Table 2. Average concentration of ions detected in the wells of Makkah.

\begin{tabular}{|c|c|c|c|c|}
\hline Locations & Nitrate & Nitrite & Chloride & Sulphate \\
\hline A & 188.88 & 0.01 & 286.38 & 436.71 \\
\hline B & 109.60 & 0.02 & 284.20 & 432.50 \\
\hline $\mathrm{C}$ & 510.00 & 0.03 & 611.20 & 980.00 \\
\hline $\mathrm{D}$ & 56.08 & 0.02 & 120.47 & 173.88 \\
\hline E & 190.83 & 0.03 & 443.00 & 396.33 \\
\hline $\mathrm{F}$ & 247.83 & 0.02 & 527.50 & 629.95 \\
\hline G & 57.33 & 0.16 & 284.00 & 318.00 \\
\hline $\mathrm{H}$ & 194.83 & 0.01 & 211.33 & 293.67 \\
\hline I & 236.00 & 0.09 & 377.00 & 681.00 \\
\hline $\mathrm{J}$ & 175.25 & 0.04 & 215.50 & 280.00 \\
\hline $\mathrm{K}$ & 70.10 & 0.03 & 137.50 & 110.00 \\
\hline $\mathrm{L}$ & 258.33 & 0.04 & 298.67 & 431.17 \\
\hline M & 404.25 & 0.01 & 344.50 & 565.50 \\
\hline $\mathrm{N}$ & 152.18 & 0.05 & 374.25 & 599.63 \\
\hline $\mathrm{O}$ & 300.00 & 0.03 & 535.00 & 1147.00 \\
\hline $\mathrm{P}$ & 132.76 & 0.08 & 191.48 & 355.67 \\
\hline Q & 55.10 & 0.03 & 143.68 & 276.00 \\
\hline $\mathrm{R}$ & 700.00 & 0.04 & 1389.00 & 1000.00 \\
\hline $\mathrm{S}$ & 266.00 & 0.01 & 258.00 & 467.50 \\
\hline$X$ & 319.71 & 0.07 & 490.57 & 793.29 \\
\hline $\mathrm{Y}$ & 47.00 & 0.00 & 89.00 & 120.00 \\
\hline $\mathrm{Z}$ & 235.00 & 0.06 & 377.00 & 271.75 \\
\hline MS & 47.97 & 0.02 & 102.00 & 171.00 \\
\hline MN & 206.40 & 0.17 & 92.00 & 130.84 \\
\hline $\mathrm{NZ}$ & 175.00 & 0.04 & 167.17 & 239.00 \\
\hline $\mathrm{BH}$ & 145.93 & 0.23 & 237.67 & 228.33 \\
\hline $\mathrm{SH}$ & 162.33 & 0.01 & 684.33 & 687.33 \\
\hline SASO & 45 & 3 & 600 & 400 \\
\hline WHO & 50 & 3 & 250 & 500 \\
\hline EPA & 50 & 1 & 250 & 250 \\
\hline EU & 45 & 0.5 & 250 & 250 \\
\hline
\end{tabular}




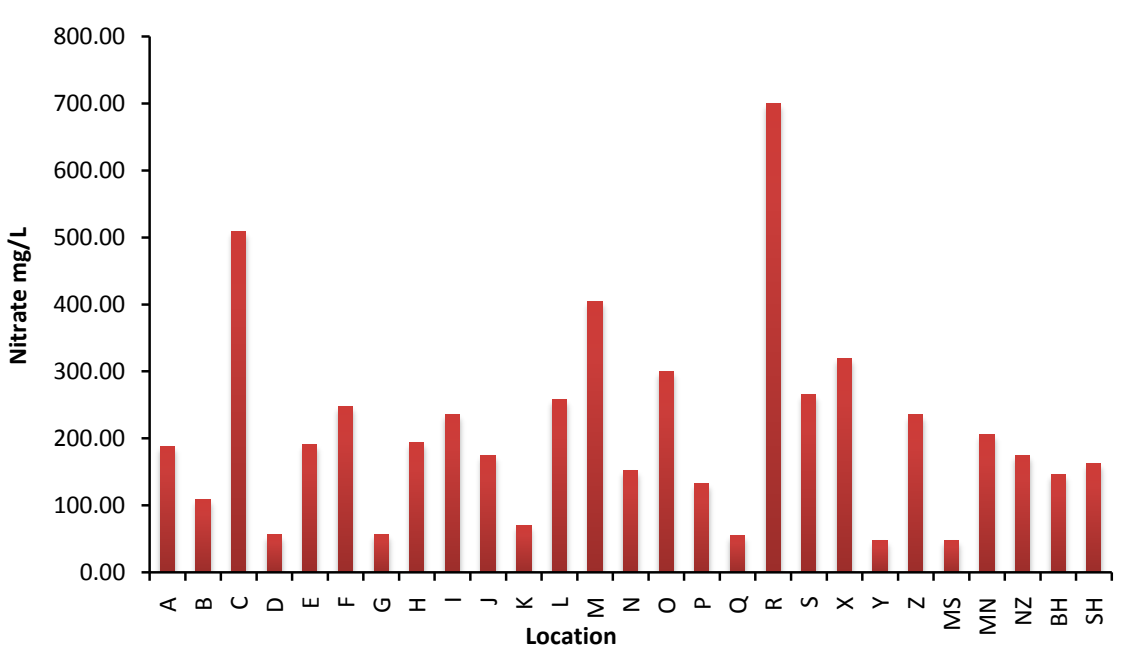

Figure 3. Average concentration of nitrate in studded locations.

be attributed to the extent of the depth of wells. Some studies have indicated that a significant reciprocal relationship could be established between well depth and nitrate content [34]. However, in the other regions of Saudi Arabia, lower concentrations of nitrate were found when compared to our study [35]-[37]. The probability of higher nitrate content in the present study is attributed to the natural nitrate accumulation due to precipitation, irrigation using groundwater containing nitrogen, dry deposition and pollution due to anthropogenic sources, such as municipal waste disposal, pesticides, etc. The distribution of the average concentrations is illustrated in Figure 4, and the intensity of the concentration is shown in the contour map in the top right corner.

The nitrite levels obtained in all the wells investigated were quiet low, and ranged from 0 to $0.3 \mathrm{mg} / \mathrm{l}$ (mean 0.04 ) as shown in Figure 5. Considering the local and international drinking water quality standards, $100 \%$ of the well water in the Makkah region was found to be good water with respect to the nitrite content. The maximum nitrite concentration $(0.38 \mathrm{mg} / \mathrm{l})$ was detected inside Makkah City, in wells 3 and 5 of Al-Twndibawi and well 1 of Batha Qurash. However, nitrite was not detected in wells 17 and 20 of Wadi Noman and 2 of Al-Omrah. The concentrations of nitrite and nitrate have no statistic relationship, because nitrite is an intermediate unstable compound in the microbial nitrogen cycle, so it could be absent or present in small concentrations. The intensity of the concentration for nitrite is shown in the contour map in the top right corner in Figure 6.

The average sulphate concentrations are shown in Figure 7, and ranged between 8.6 and $1400 \mathrm{mg} / \mathrm{l}$, with an average concentration of $452 \mathrm{mg} / \mathrm{l}$. In the total of 145 well water samples, $38.6 \%$ were found to fall above the SASO (1984) standard limits, $41 \%$ above the WHO (2010) and 65.5\% above the EPA (2011) and EU (1998) standards. Naturally, sulphate occurs in many water sources coming in contact with particular rock strata and mineral deposits. The average sulphate concentration in this study is less than that in the studies conducted in the groundwater samples of Mushait, Aseer, Saudi Arabia (524.20 mg/l) [35], and higher than in the reports of the hydrochemistry of the aquifer system at Wadi An Numan, Makkah Al Mukarramah, Saudi Arabia (262 mg/l) [33]. The highest sulphate concentration of $30-400 \mathrm{mg} / \mathrm{l}$ indicated the taste threshold level (Viessman and Hammer, 1985). According to the EPA (2011), sulphate has a secondary maximum contaminant level (SMCL) of $250 \mathrm{mg} / \mathrm{L}$ based on aesthetic effects (taste and odour). The intensity of the concentration for sulphate is shown in Figure 8, and in the contour map in the upper right corner.

The chloride concentration varied from 25 to $1389 \mathrm{mg} / \mathrm{l}$, with an average value of $334 \mathrm{mg} / \mathrm{l}$ (Figure 9). The SASO (1984) states that the optimum value of the concentration of the chloride content in a water sample is 200 $\mathrm{mg} / \mathrm{l}$, and that the maximum permissible limit is $600 \mathrm{mg} / \mathrm{l}$. Using these standards, $90 \%$ of the water samples were of the best quality water with respect to chloride content; whereas, $67 \%$ of the water samples over reach the maximum limit recommended by the EPA, WHO and European Union. The WHO guidelines for the presence of chloride were based on taste rather than on health, therefore, higher values can be tolerated (WHO, 2003). In previous studies carried out in Saudi Arabia on well water samples taken from Makkah and Southwestern Saudi Arabia, the average chloride concentrations were found to be 205 and $206 \mathrm{mg} / \mathrm{l}$, respectively [35]. However, in the $\mathrm{Al}$ Gassim region, the mean chloride values of $363 \mathrm{mg} / \mathrm{l}$ were found to be very close to those in our study [36]. The minimum concentration $(25 \mathrm{mg} / \mathrm{l})$ was found in Wadi Noman. The presence of higher amounts 


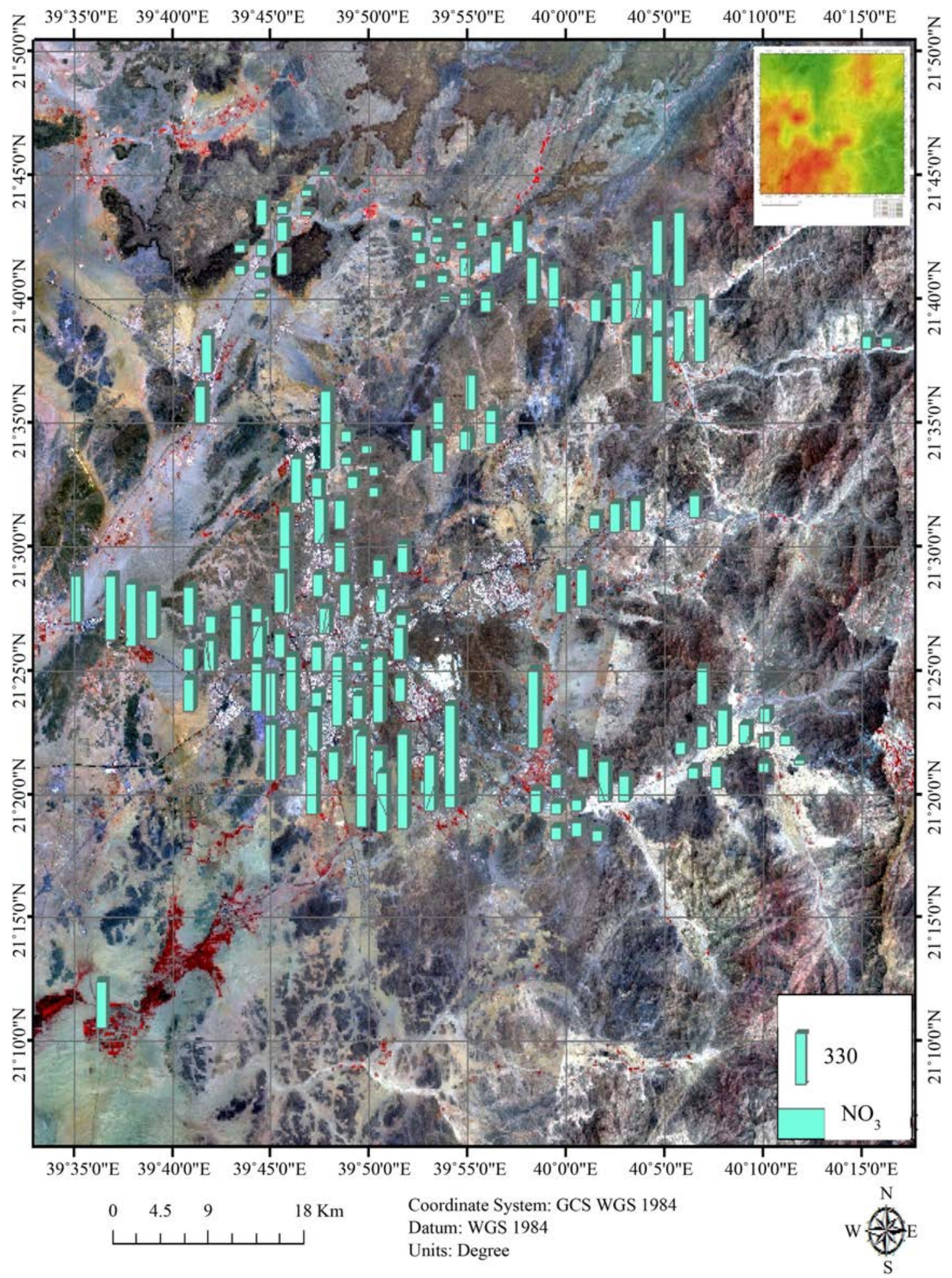

Figure 4. Distribution of nitrate in Makkah well water.

of chloride, as noted in the present study, may be due to natural processes such as the passage of water through the natural salt formation in the earth. The intensities of the concentrations of chloride are shown in Figure 10, and on the contour map in the upper right corner. 


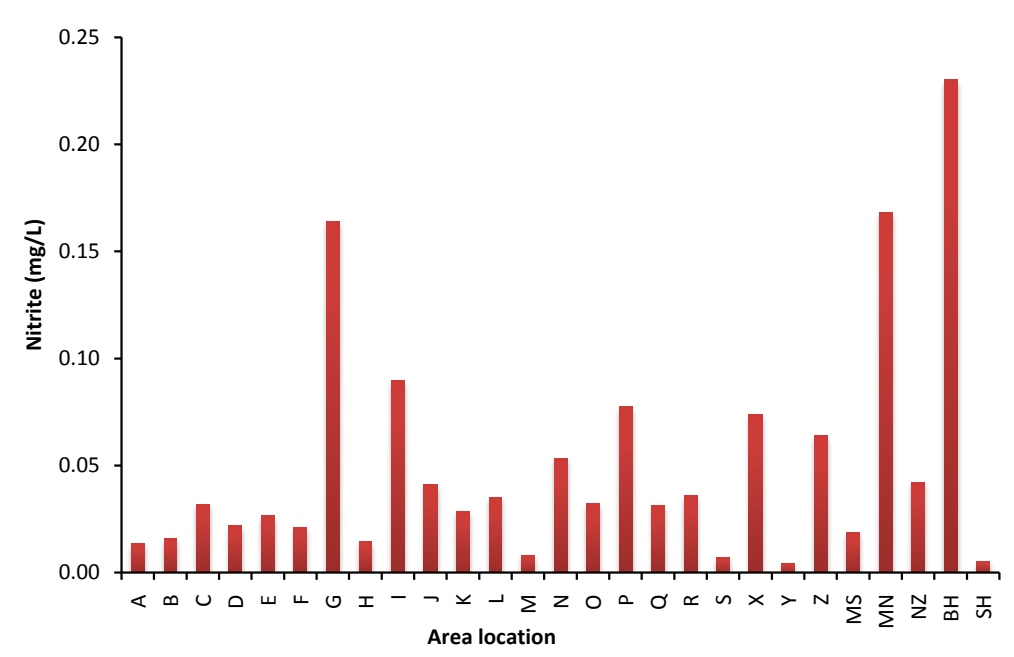

Figure 5. Average concentration of nitrite in various locations.

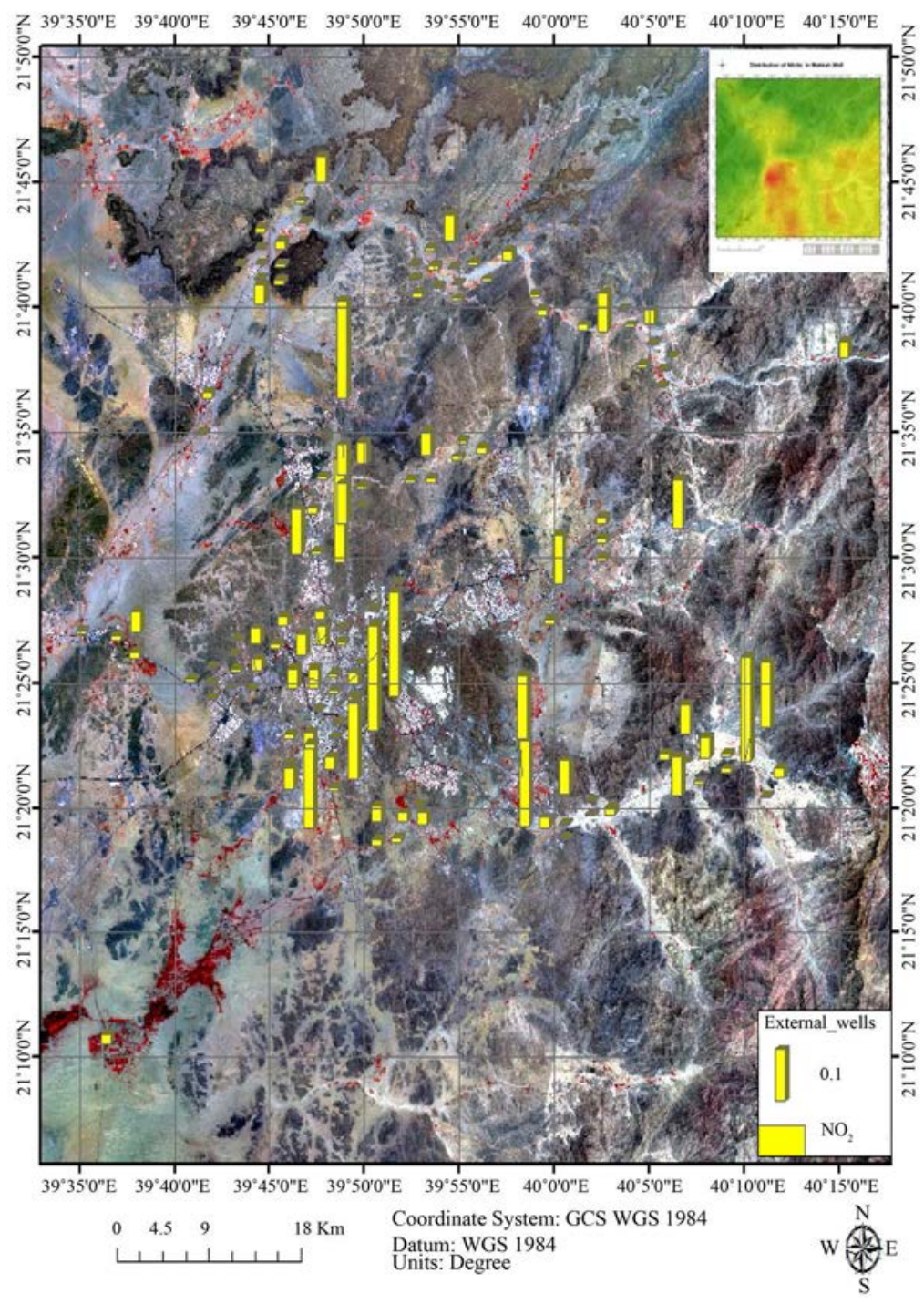

Figure 6. Distribution of nitrite in Makkah well water. 


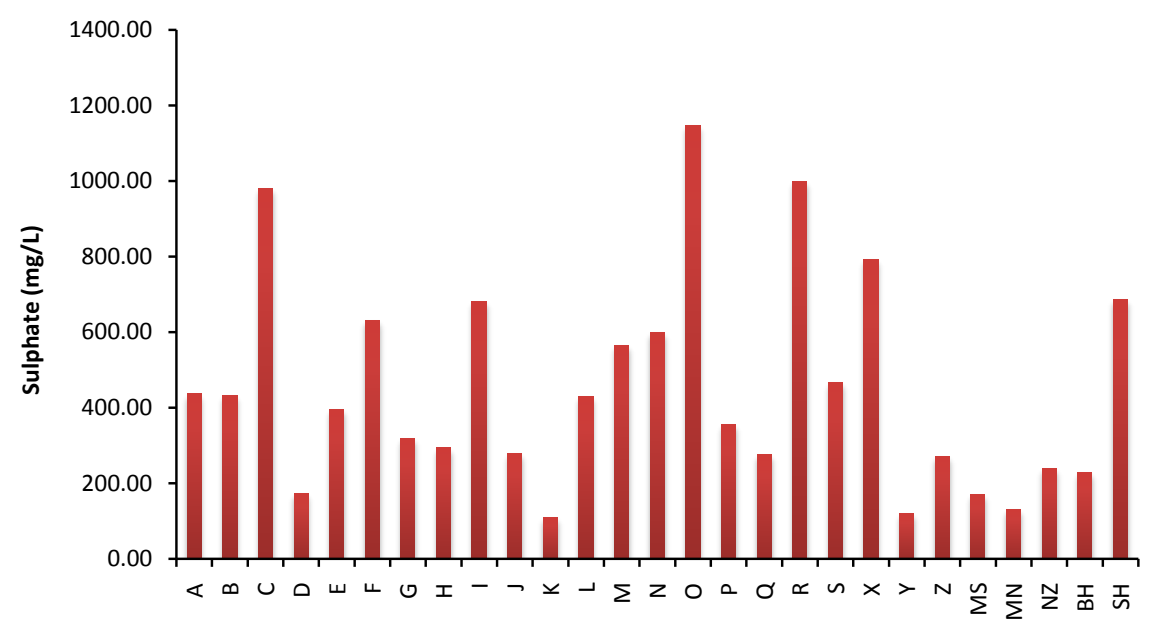

Area Location

Figure 7. Average concentration of sulphate in various locations.

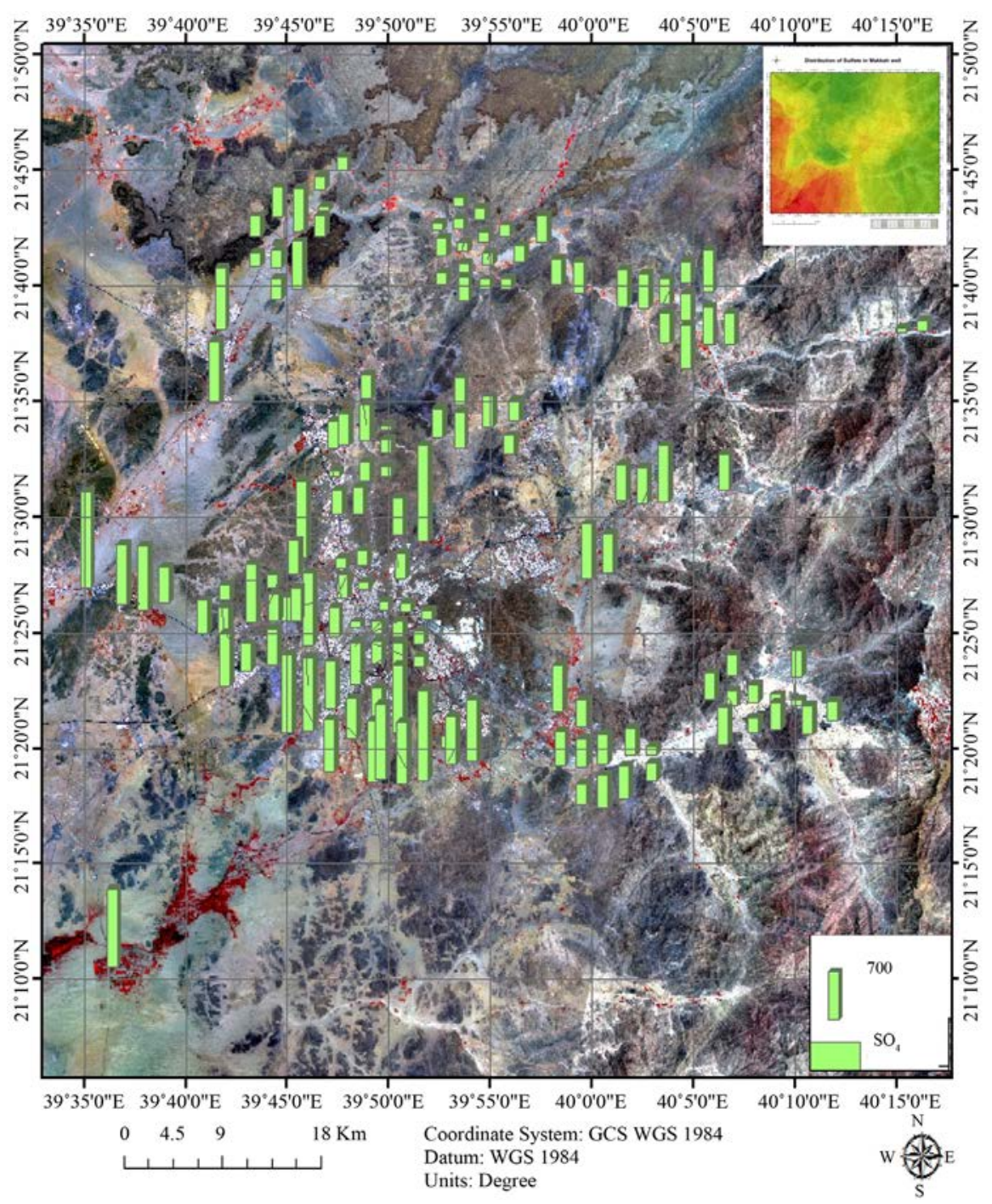

Figure 8. Distribution of sulphate in Makkah well water. 


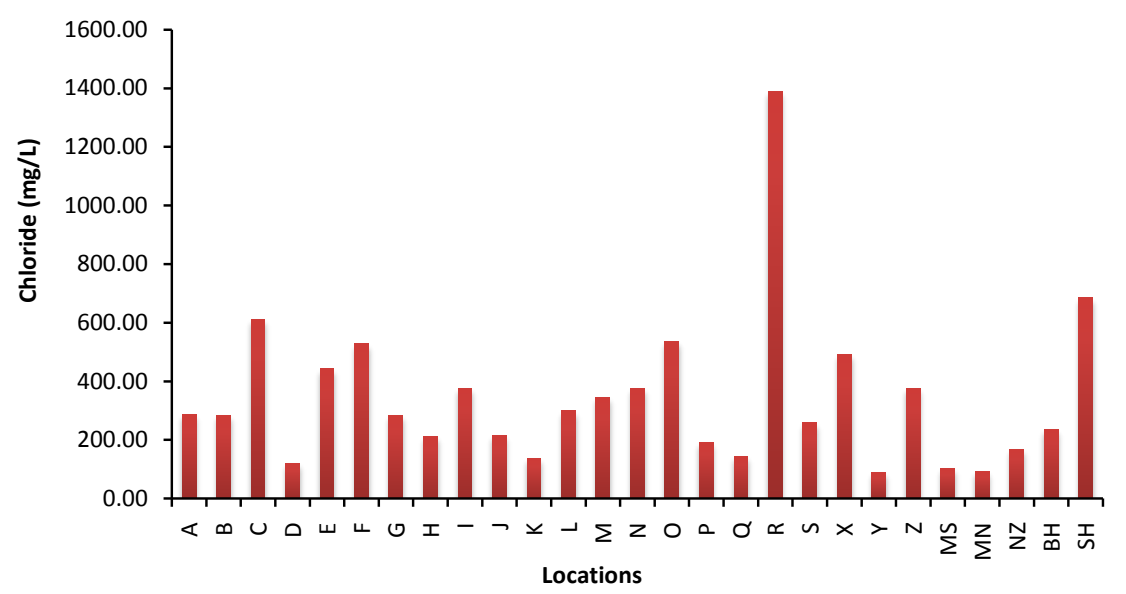

Figure 9. Average concentration of chloride in various locations.

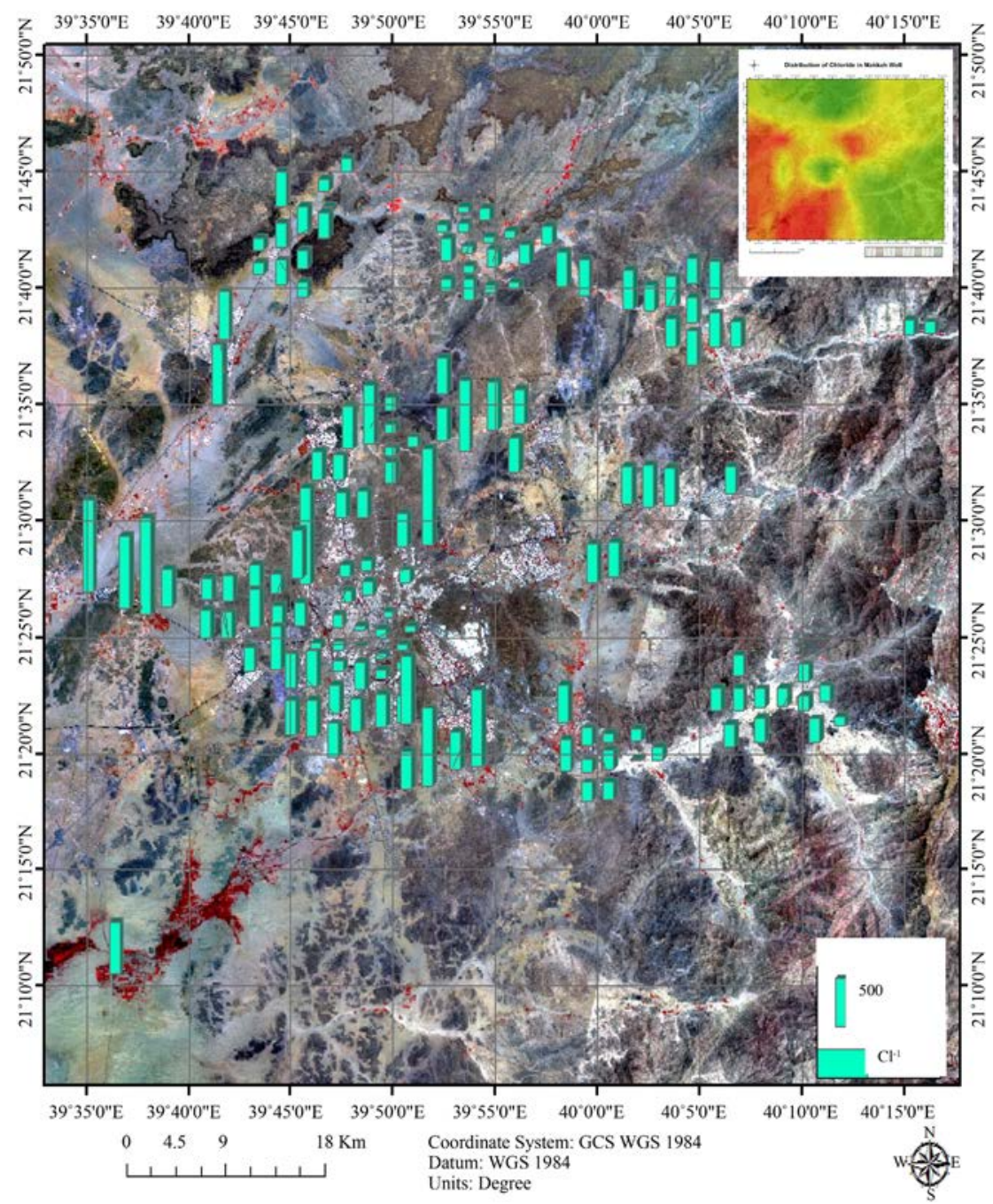

Figure 10. Distribution of chloride in Makkah well water.

The wells with the maximum and minimum concentrations of four ions found in different locations are shown in Table 3 and Table 4. The maximum concentrations of all ions exceeded the local and international standards, 
Table 3. Maximum levels of ions detected in Makkah wells.

\begin{tabular}{|c|c|c|c|c|c|}
\hline Parameter & $\begin{array}{l}\text { Max. } \\
(\mathrm{mg} / \mathrm{l})\end{array}$ & $\begin{array}{l}\text { No. of } \\
\text { well }\end{array}$ & $\begin{array}{l}\% \text { No. of } \\
\text { well }\end{array}$ & Area name and well code & Relationship to standard \\
\hline Nitrite & 0.38 & 3 & 2.1 & $\begin{array}{c}\text { AL-Twndibawi MN 3, MN 5, } \\
\text { Batha Quraysh BH } 1\end{array}$ & Within standards \\
\hline Nitrate & 700 & 1 & 0.7 & Al-Fihah, R1 & Exceeds all standards \\
\hline Chloride & 1389 & 2 & 1.4 & Al-Fihah R1, Al-Hajj Road SH 1 & Exceeds all standards \\
\hline Sulphate & 1400 & 1 & 0.7 & Al-Shumaisi F2 & Exceeds all standards \\
\hline
\end{tabular}

Table 4. Minimum levels of ions detected in Makkah wells.

\begin{tabular}{ccccc}
\hline Parameters & Min. (mg/l) & No. of well & \% No. of well & Area and location \\
\hline Nitrite & 0 & 3 & 2.1 & Wadi Noman P 17, 20 and Al-Omrah Z2 \\
Nitrate & 23 & 1 & 0.7 & Al-Jamoom B8 \\
Chloride & 25 & 1 & 0.7 & Wadi Noman P3 \\
Sulphate & 8.6 & 1 & 0.7 & Al-Shumaisi F1 \\
\hline
\end{tabular}

with the exception of nitrite. The maximum nitrite concentration $(0.38 \mathrm{mg} / \mathrm{l})$ was detected inside Makkah City, in wells 3 and 5 of Al-Twndibawi and well 1 of Batha Qurash. However, nitrite was not detected in wells 17 and 20 of Wadi Noman and well 2 of Al-Omrah. The maximum $\mathrm{NO}_{3}$ and $\mathrm{Cl}^{-1}$ concentrations were found in wells 1 $(0.7 \%)$ and $2(1.4 \%)$ distributed inside the city. The minimum and maximum concentrations of sulphate were found in the wells outside the city; the maximum $(1400 \mathrm{mg} / \mathrm{l})$ and minimum $(8.6 \mathrm{mg} / \mathrm{l})$ were found in wells 2 and 1, respectively, in the Al-Shumaisi region. The highest nitrate and chloride levels were detected in the AlFihah area in well number 1 and high chloride levels were also found in well 1 on Al-Hajj Road. The minimum concentrations were observed in Al-Jamoom 8 and Wadi Noman 3, respectively. The high levels of nitrate, sulphate and chloride could be due to anthropogenic contamination, such as industrial waste, municipal waste and contamination due to the composition of the rock, which has an impact on the water quality.

\section{Conclusion}

With regard to the presence of four ions studied in the well water of Makkah City and the surrounding area, nitrate was found to be the most accumulated ion based on national and international standards. The water containing high nitrate levels is unsuitable for drinking without proper treatment. Chloride and sulphate were also present in the water samples. The regular monitoring of ground water quality and the introduction of modern waste disposal facilities are some of the best options to reduce this contamination. This work provides a building block for future research using GIS for monitoring water contamination and shows the distribution of four different ions $\left(\mathrm{SO}_{4}, \mathrm{Cl}, \mathrm{NO}_{3}\right.$ and $\left.\mathrm{NO}_{2}\right)$ in 27 areas of Makkah City. Further study is going on to evaluate heavy metals and other health related ions using GIS Technique.

\section{Acknowledgements}

The authors thank the Ministry of Health, Makkah Health Affairs for the use of the facilities and equipment at the Makkah Toxicology Centre during Phase I of this study. Many thanks to King Abdulaziz City for Science and Technology (KACST) for the funding of Phase II of this work under project number 33-817, and supporting us in using their satellite images.

\section{References}

[1] King Khalid bin Abdulaziz Database (2014) First Addition. www.kingkhalid.org.sa/gallery/text/info.aspx?ID=23

[2] Khdary, N.H. and Turkistani, A.H.M. (2009) Using Total Dissolved Substances (TDS) to Recognize the Sources of Drinking Water in Central Area of Makkah Al-Mukaramah. Journal of Saudi Chemical Society, 409, 29-36.

[3] McMurry, J. and Fay, R. (2004) Hydrogen, Oxygen and Water. In: Hamann, K.P., Ed., McMurry Fay Chemistry, 4th Edition, Pearson Education, New Jersey, 575-599. 
[4] Mendie, U. (2005) The Nature of Water. The Theory and Practice of Clean Water Production for Domestic and Industrial Use. Lacto-Medals Publishers, Lagos, 1-21.

[5] Al-Hasawi, Z. and Hussein, K. (2012) Groundwater Investigation in Rabigh Governorate, West of Saudi Arabia. Global Advanced Research Journal of Environmental Science and Toxicology, 1, 72-79.

[6] Al-Ahmadi, M.E. (2005) Groundwater Quality in Some Villages Northeast of Jeddah City, Saudi Arabia. 9th International Water Technology Conference, 3, 387-390.

[7] Khdary, N.H. and Gassim, A.E. (2014) The Distribution and Accretion of Some Heavy Metals in Makkah Wells. Journal of Water Resources and Protection, 6, 998-1010. http://dx.doi.org/10.4236/jwarp.2014.611094

[8] Al-Ibrahim, A.A. (1990) Water Use in Saudi Arabia: Problems and Policy Implications. Journal of Water Resources Planning and Management, 116, 375-388. http://dx.doi.org/10.1061/(ASCE)0733-9496(1990)116:3(375)

[9] Al-Solami, A., Al-Barakati, G., Sayed, S.A.S., Al-Bahloul, S. and Al-Tunsi, B. (2009) Engineering Geological Mapping of the Holy City of Makkah Al Mukarramah, Saudi Arabia. Engineering Geology of Tomorrow's Cities. Geological Society, Engineering Geology Special Publication, London, 22.

[10] Almasri, M.N. and Kaluarachchi, J.J. (2004) Assessment and Management of Long-Term Nitrate Pollution of Ground Water in Agriculture-Dominated Watersheds. Journal of Hydrology, 295, 225-245. http://dx.doi.org/10.1016/j.jhydrol.2004.03.013

[11] UNEP (2003) Desk Study on the Environment in the Occupied Palestinian Territories. United Nations Environment Programme, Nairobi.

[12] Nas, B. and Berktay, A. (2006) Groundwater Contamination by Nitrates in the City of Konya, (Turkey): A GIS Perspective. Journal of Environmental Management, 79, 30-37. http://dx.doi.org/10.1016/j.jenvman.2005.05.010

[13] Sunitha, V. (2013) Nitrates in Groundwater: Health Hazards and Remedial Measures. Indian Journal of Advances in Chemical Science, 1, 164-170.

[14] Birkinshaw, S.J. and Ewen, J. (2000) Nitrogen Transformation Component for SHETRAN Catchment Nitrate Transport Modelling. Journal of Hydrology, 230, 1-17. http://dx.doi.org/10.1016/S0022-1694(00)00174-8

[15] Saadi, M. (2003) Modelling Nitrogen Dynamics in Unsaturated Soils for Evaluating Nitrate Contamination of the Mnasra Groundwater. Advances in Environmental Research, 7, 803-823. http://dx.doi.org/10.1016/S1093-0191(02)00055-2

[16] Alabdula'aly, A.I., Al-Rehaili, A.M., Al-Zarah, A.I. and Khan, M.A. (2010) Assessment of Nitrate Concentration in Groundwater in Saudi Arabia. Environmental Monitoring and Assessment, 161, 1-9. http://dx.doi.org/10.1007/s10661-008-0722-7

[17] Anayah, F.M. and Almasri, M.N. (2009) Trends and Occurrences of Nitrate in the Groundwater of the West Bank, Palestine. Applied Geography, 29, 588-601. http://dx.doi.org/10.1016/j.apgeog.2009.01.004

[18] Hall, M.D., Shaffer, M.J., Waskem, R.M. and Delgado, J.A. (2001) Regional Nitrate Leaching Variability: What Makes a Difference in Northeastern Colorado. Journal of the American Water Resources Association, 37, 139-150. http://dx.doi.org/10.1111/j.1752-1688.2001.tb05481.x

[19] Eskiocak, S., Dundar, C., Basoglu, T. and Altaner, S. (2005) The Effects of Taking Chronic Nitrate by Drinking Water on Thyroid Functions and Morphology. Journal of Clinical and Experimental Medicine, 5, 66-71. http://dx.doi.org/10.1007/s10238-005-0068-1

[20] Brender, J.D., Olive, J.M., Felkner, M., Suarez, L., Marckwardt, W. and Hendricks, K.A. (2004) Dietary Nitrites and Nitrates, Nitro Stable Drugs, and Neural Tube Defects. Epidemiology, 15, 330-336. http://dx.doi.org/10.1097/01.ede.0000121381.79831.7b

[21] Moncaster, S.J., Botrell, S.H., Tellam, J.H., Llyod, J.W. and Konhauser, K.O. (2000) Migration and Attenuation of Agro Chemical Pollutants: Insights from Isotopic Analysis of Groundwater Sulphate. Journal of Contaminant Hydrology, 43, 147-163. http://dx.doi.org/10.1016/S0169-7722(99)00104-7

[22] Greenwood, N.N. and Earnshaw, A. (1984) Chemistry of the Elements. Pergamon Press, Oxford.

[23] Li, X.D., Masuda, H., Kusakabe, M., Yanagisawa, F. and Zeng, H.A. (2006) Degradation of Groundwater Quality Due to Anthropogenic Sulphur and Nitrogen Contamination in the Sichuan Basin, China. Geochemical Journal, 40, 309332. http://dx.doi.org/10.2343/geochemj.40.309

[24] WHO (2004) Sulphate in Drinking-Water-Background Document for Development. WHO Guidelines for DrinkingWater Quality.

[25] EPA (1999) Health Effects from Exposure to High Levels of Sulphate in Drinking Water Study. US Environmental Protection Agency, Washington DC.

[26] Miao, Z., Brusseau, M.L., Carroll, K.C., Carreun-Diazconti, C. and Johnson, B. (2012) Sulphate Reduction in Ground 
Water; Characterization and Application for Remediation. Environment Geochemical Health, 34, 539-550. http://dx.doi.org/10.1007/s10653-011-9423-1

[27] Langmuir, D. (1991) Aqueous Environmental Geochemistry. Prentice-Hall, Englewood Cliff.

[28] WHO (2003) Chloride in Drinking-Water-Background Document for Development. WHO Guidelines for DrinkingWater Quality.

[29] Sameer, V.Y., Hampannavar, U.S. and Purandara, B.K. (2011) Assessment of Chloride Concentration in Groundwater: A Case Study for Belgaum City. International Journal of Environmental Sciences, 2, 271-280.

[30] Sawyer, C.N., McCarty, P.L. and Parkin, G.F. (2003) Chemistry for Environmental and Engineering Science. 5th Edition, McGraw Hill Inc., New York, 587-590.

[31] Sivakumar, K.K., Deenadayalan, M.S., Hebsibhai, L., Kalivani, T.R. and Mahalakshmi, S. (2011) Behaviour of Chloride and Sodium Contaminations in Ground Water. Journal of Chemical, Biological and Physical Sciences, 1, 213-219.

[32] EURO Reports and Studies 2 (1978) Sodium, Chlorides, and Conductivity in Drinking Water. WHO Regional Office for Europe, Copenhagen.

[33] Sharaf, M.A.M. (2011) Hydrogeology and Hydrochemistry of the Aquifer System of Wadi An Numan, Makkah Al Mukarramah, Saudi Arabia. AQUA Mundi, 035-052.

[34] Al-Turki, A.I. and Abdel Magid, H.M. (2003) Nitrate Content of Drinking and Irrigation Water in Al-Qassim Region-Central Saudi Arabia, Mansura. Journal of Agricultural Science, 11, 7943-7950.

[35] Al-Otaibi, E.L. and Zaki, M.S.A. (2009) Physico-Chemical Quality of Drinking Water at Mushait, Aseer, South Western Saudi Arabia. African Journal of Clinical and Experimental Microbiology, 10, 117-127.

[36] Al-Redhaiman, K.N. and Abdel Magid, H.M. (2002) The Applicability of the Local and International Water Quality Guidelines to Al-Gassim Region of Central Saudi Arabia. Water, Air, and Soil Pollution, 137, 235-246. http://dx.doi.org/10.1023/A:1015550417199

[37] Al-Harbi, N.A. (2010) Physico-Chemical Properties of Well Waters in Al-Yanfa Village, Asir Region, Saudi Arabia. Journal of Food, Agriculture \& Environment, 8, 965-967. 